\title{
Macronutrient Intake in Pregnancy and Child Cognitive and Behavioural Outcomes
}

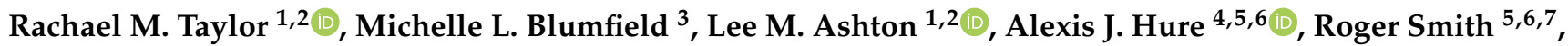 \\ Nick Buckley ${ }^{8}$, Karen Drysdale ${ }^{9}$ and Clare E. Collins ${ }^{1,2,6, * \mathbb{D}}$
}

1 Priority Research Centre in Physical Activity and Nutrition, University of Newcastle, Callaghan, NSW 2308, Australia; rachael.taylor@newcastle.edu.au (R.M.T.); lee.ashton@newcastle.edu.au (L.M.A.)

2 Faculty of Health and Medicine, School of Health Sciences, University of Newcastle, Callaghan, NSW 2308, Australia

3 Department of Nutrition, Dietetics and Food, Faculty of Medicine, School of Clinical Sciences, Nursing and Health Sciences, Monash University, Clayton, VIC 3800, Australia; michelleblumfield@bigpond.com

4 Priority Research Centre for Generational Health and Ageing, University of Newcastle, Callaghan, NSW 2308, Australia; alexis.hure@newcastle.edu.au

5 Faculty of Health and Medicine, School of Medicine and Public Health, University of Newcastle, Callaghan, NSW 2308, Australia; roger.smith@newcastle.edu.au

6 Hunter Medical Research Institute, 1 Kookaburra Circuit, New Lambton Heights, NSW 2305, Australia

7 Priority Research Centre for Reproductive Science, University of Newcastle, Callaghan, NSW 2308, Australia

8 School of Psychology and Exercise Science, Murdoch University, Murdoch, WA 6150, Australia; nick.buckley@gmail.com

9 Faculty of Science, School Psychology, University of Newcastle, Callaghan, NSW 2308, Australia; karen.drysdale@newcastle.edu.au

check for
updates

Citation: Taylor, R.M.; Blumfield, M.L.; Ashton, L.M.; Hure, A.J.; Smith, R.; Buckley, N.; Drysdale, K.; Collins, C.E. Macronutrient Intake in Pregnancy and Child Cognitive and Behavioural Outcomes. Children 2021 8, 425. https://doi.org/ $10.3390 /$ children 8050425

Academic Editor: Ann-Marie Malby Schoos

Received: 13 April 2021

Accepted: 18 May 2021

Published: 20 May 2021

Publisher's Note: MDPI stays neutral with regard to jurisdictional claims in published maps and institutional affiliations.

Copyright: (C) 2021 by the authors. Licensee MDPI, Basel, Switzerland. This article is an open access article distributed under the terms and conditions of the Creative Commons Attribution (CC BY) license (https:/ / creativecommons.org/licenses/by/ $4.0 /)$.
* Correspondence: clare.collins@newcastle.edu.au; Tel.: +61-2-492-156-46; Fax: +61-2-492-170-53

\begin{abstract}
Prenatal nutrient exposures can impact on brain development and disease susceptibility across the lifespan. It is well established that maternal macronutrient intake during pregnancy influences foetal and infant development. Therefore, we hypothesise that macronutrient intakes during pregnancy are correlated with cognitive development during early childhood. The current study aimed to investigate the relationship between maternal macronutrient intake during pregnancy and child cognitive and behavioural outcomes at age 4 years. We analysed prospective data from a cohort of 64 Australian mother-child dyads. Maternal macronutrient intake was assessed using a validated 74-item food frequency questionnaire at 2 timepoints during pregnancy. Child cognition and behaviour were measured at age 4 years using the validated Wechsler Preschool and Primary Scale of Intelligence, 3rd version (WPPSI-III) and the Child Behaviour Checklist (CBC). Linear regression models were used to quantify statistical relationships and were adjusted for maternal age, education, pre-pregnancy BMI, breastfeeding duration and birthweight. Child Performance IQ was inversely associated with maternal starch intake $(b=-11.02, p=0.03)$. However, no other associations were found. Further research is needed to explore the association between different types of starch consumed during pregnancy and child cognitive development.
\end{abstract}

Keywords: pregnancy; nutrition; cognition; behaviour; development; macronutrients

\section{Introduction}

The Developmental Origins of Health and Disease $(\mathrm{DOHaD})$ hypothesis postulates that environmental exposures in utero or during the postnatal period may alter developmental physiology and susceptibility to disease across the lifespan [1]. Inadequate nutrition during pregnancy and the first 3 years of life may result in permanent functional changes in the brain and lead to psychopathology including schizophrenia [2] and antisocial externalizing behaviour, as this period is critical for brain growth [3,4]. Approximately 2 to 3 weeks after conception, foetal brain growth commences with the formation of the neural 
tube [5]. This is followed by significant neuronal proliferation, differentiation and migration during early gestation (8-22 weeks) [5]. Synaptogenesis, apoptosis and myelination are life-long neurological processes that commence during late gestation (24-35 weeks gestation) [5]. Adequate nutrients are necessary for the functioning of these neurodevelopmental processes [6].

The link between maternal nutrition and foetal brain development is clearly established from the analyses of offspring from the Dutch Winter Hunger famine of 1944$1945[7,8]$. These studies report that the risk of a psychiatric disorder during adulthood was higher in the offspring that were exposed to severe prenatal famine $[7,8]$. Emerging evidence also suggests that maternal overnutrition, an energy imbalance resulting in overweight and obesity, is associated with behavioural disorders in the offspring including attention deficit-hyperactivity disorder and autism spectrum disorder [9-11]. The functional changes in the brain caused by maternal nutritional insults maybe partially explained by epigenetic mechanisms including DNA methylation [12-14]. Studies conducted in the Gambia, a country in West Africa, indicate that seasonal fluctuations in maternal nutrient intake are correlated with DNA methylation patterns in the offspring at $2-8$ months $[15,16]$. These findings suggest that adequate maternal nutrition is important for preventing aberrant DNA methylation patterns and phenotypes.

Maternal macronutrient intake is known to impact on foetal and infant growth [17-20]. Sloan et al. (18) reported that both low-protein $(<50 \mathrm{~g})$ and high-protein $(\geq 85 \mathrm{~g})$ during pregnancy has a quadratic (U-shaped) relation with foetal growth. Evidence suggests that impaired placental transport and umbilical uptake of amino acids may explain this relationship [21-23]. The Women and Their Children's Health (WATCH) study, a prospective longitudinal birth cohort of 156 mother-child dyads, previously reported that maternal macronutrient profile was associated with foetal body composition [24]. Higher foetal abdominal fat was correlated with low maternal protein intake $(<16 \%$ of total energy), while mid-thigh fat was highest at intermediate protein (18-21\% of total energy), high fat ( $>40 \%$ of total energy) and low carbohydrate ( $<40 \%$ of total energy) intake [24]. While analysing the impact of maternal macronutrient intake on foetal and infant brain composition is not ethical in living human subjects, animal models have shown that protein restriction during pregnancy impairs the micro-structure of the foetal brain rather than altering the total brain weight [25]. A low protein intake during pregnancy adversely affects dendrite numbers [26], morphology of hippocampal cells [27], mossy fibre (MF) axonal area $[28,29]$, synaptic spine complexity $[27,30]$ and polyunsaturated fatty acid (PUFA) brain content $[31,32]$. Furthermore, animal studies have shown that maternal protein restriction is correlated with deficits in cognitive and behavioural function in offspring [30,33-35].

Currently, at a global and national scale, there is a lack of public health strategies for the prevention neurodevelopmental disorders [36]. Given the known link between maternal nutrition during pregnancy and future of health of the offspring [1], nutrition is one area that could be targeted. To date, human studies have primarily focused on the consequences of maternal micronutrient intake rather than macronutrient profile on child cognitive and behavioural function $[37,38]$. This is important as macronutrients (carbohydrates, protein and fat) are the main contributors to maternal and foetal energy intake, which is essential for foetal cellular and tissue growth [17-19]. In the human brain, glucose derived from dietary carbohydrates is the primary energy source; protein is required for the synthesis of neurotransmitters, enzymes and cell membranes; fat is abundant in the structural matrix of cell membranes, as well as myelin [39,40]. These roles and functions indicate that macronutrients are essential for optimal brain development and function. We hypothesise that maternal macronutrient profile during pregnancy is associated with child cognitive outcomes. This evidence will be important for informing dietary recommendations during pregnancy for supporting optimal child cognitive development and preventing neurodevelopmental disorders. Therefore, the aim of the current study was to investigate the relationship between maternal macronutrient intake during pregnancy on child cognitive and behavioural outcomes at age 4 years in an Australian population. 


\section{Materials and Methods}

\subsection{Study Population}

The current study analysed prospective data from pregnant women and their children enrolled in The Women and Their Children's Health (WATCH) study [41]. Pregnant women were recruited from the antenatal clinic at the John Hunter Hospital (JHH), New South Wales (NSW), Australia, from July 2006 to December 2008. Women were eligible for this study if they were: (1) less than 18 weeks pregnant, (2) lived in the local or neighbouring areas, and (3) were able to attend the JHH for study visits. Women were recruited by midwives, local media coverage, or by word of mouth. A consent rate of $61 \%$ was achieved for the pregnant women who were approached to participate in this study and 182 women were enrolled [42]. The recruitment, withdrawals and attendance of study participants have been described previously [43]. Women attended study visits during pregnancy at approximately 19, 24, 30 and 36 weeks gestation. Women and their children attended postnatal study visits at 3-monthly intervals during the first 12 months after birth, and then annually until the age of 4 years. Study visit attendance and participant withdrawals are reported in Figure 1. The WATCH study received ethics approval from the Hunter New England Research Ethics Committee (06/05/24/5.06) and therefore has been performed in accordance with the ethical standards laid down in the 1964 Declaration of Helsinki and its later amendments. All participants gave written informed consent prior to their inclusion in this study. The reporting of this study adheres to The Strengthening the Reporting of Observational Studies in Epidemiology (STROBE) Statement: guidelines for reporting observational studies [44].

\subsection{Dietary Assessment}

Dietary assessment methods used in the WATCH study have been described in detail elsewhere [24,41,45]. Briefly, dietary data during pregnancy were collected between 18 and 24 weeks and again between 36 and 40 weeks gestation. Dietary data were collected using the validated food frequency questionnaire (FFQ) and the Dietary Questionnaire for Epidemiological studies (DQES) version 2 [46]. The DQES has previously demonstrated an acceptable level of accuracy for estimating nutrient intake compared to 7 day weighed food records in women $(n=63)$ of child-bearing age [47]. The self-administered questionnaire required the women to use a 10-point frequency scale to report usual consumption of 74 foods (excluding vitamin and mineral supplements) and 6 alcoholic beverages over the previous 3 months. The 10-point frequency scale using categories ranged from never to three or more times per day. Photographs were used to represent different serving sizes for vegetables, potatoes and meat casserole dishes [46]. These photographs enabled the calculation of a portion factor to account for variations in serving size. The dietary data collected between 18 and 24 weeks and again between 36 and 40 weeks of gestation are referred to as reference periods of 6-24 weeks of gestation (early pregnancy) and 24-40 weeks of gestation (late pregnancy), respectively. The WATCH cohort has previously reported positive pairwise correlations between all dietary variables in early and late pregnancy $(0.46<r<0.78 ; p<0.001)$ [24]. Therefore, maternal dietary intakes during pregnancy were expressed as the mean of intakes during early and late pregnancy. 


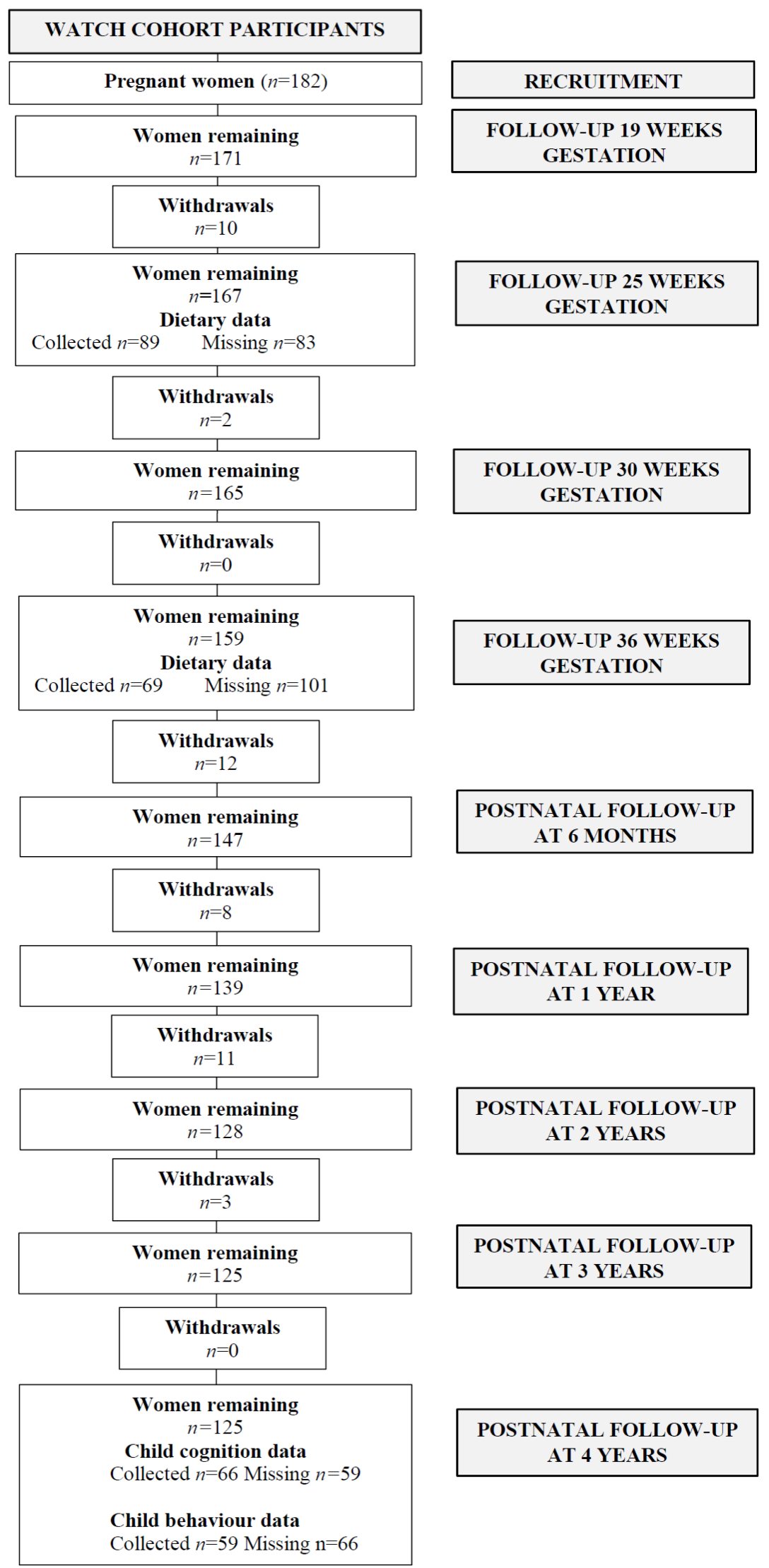

Figure 1. Flowchart of mother-child pairs enrolled in the WATCH cohort and included in the statistical analysis. 


\subsection{Dietary Analysis}

The DQES is a computer-scannable questionnaire purchased at a price that includes dietary analysis by the FFQ distributor, Cancer Council Victoria. Nutrient intakes were quantified from the Nutrient Tables-1995 (NUTTAB-1995) database. Dietary analysis results were provided in a Microsoft Excel format to facilitate data importation for statistical analysis.

\subsection{Cognition and Behavioural Assessment}

\subsubsection{Cognition}

Child cognition was assessed using the Wechsler Preschool and Primary Scale of Intelligence (WPPSI-III Australian) [48] which is suitable for children aged 4 to 7.3 years (PsychCorp, Sydney, Australia). The cognitive assessments were individually administered by a research psychologist at the 4 year study visit. The WPPSI-III is widely cited for preschool children and has satisfactory criterion validity, correlating with the Wechsler Preschool and Primary Scale of Intelligence, revised version (WPPSI-R), the Wechsler Intelligence Scale for Children, 3rd edition (WISC-III) and the Wechsler Intelligence Scale for Children, 4th edition (WISC-IV) [49,50]. The scale produces 3 main composite scoresthe Full Scale Intelligence Quotient (FSIQ), the Performance Intelligence Quotient (PIQ) and the Verbal Intelligence Quotient (VIQ) — as well as 2 additional composite scores, the Processing Speed Quotient (PSQ) and the General Language Composite (GLC). The PIQ is derived from the scores of 5 subtests, which include Block Design, Matrix Reasoning, Picture Concepts, Picture Completion and Object Assembly. The VIQ is derived from scores of 5 subtests, which include information, vocabulary, word reasoning, comprehension and similarities. The PSQ is derived from the scores of 2 subtests- symbol search and coding. The GLC is derived from the scores of 2 subtests - receptive vocabulary and picture naming. The raw scale scores were converted to standardised scores according to the child's age. The Full Scale IQ is the combined standardised scores derived from both the Performance IQ and Verbal IQ. All composite scores have a mean of 100 and a standard deviation of 15 .

\subsubsection{Behaviour}

Child behaviour was assessed using the Child Behaviour Checklist (CBC) for children aged 1.5 to 5 years [51], which has demonstrated internal accuracy of the scale across 22 countries, including Australia [52]. The behaviour assessments were completed by the primary caregiver of the child during their 4 year study visit. The checklist contains 113 behavioural/emotional problem items (questions) in 8 syndrome scales. The syndrome scales include anxious/depressed, withdrawn/depressed, somatic complaints, social problems, thought problems, attention problems, rule-breaking behaviour, and aggressive behaviour. The first 3 syndrome scales (anxious/depressed, withdrawn-depressed, and somatic complaints scores) combined to produce the internalizing problems score (internalizing broadband scale), and the last 2 syndrome scales (rule-breaking and aggressive behaviour) produce the externalizing problems score (externalizing broadband scale). The Total Behaviour Problem Scale summarises the scores obtained across all scale scores. The checklist items are rated by the child's parent on a 3-point scale, 'not true' ( 0 point), 'sometimes true' ( 1 point) and 'often true' ( 2 points). Scores of the scales are interpreted as normal, borderline or clinical behaviour.

\subsubsection{Participant Characteristics}

Sociodemographic, maternal, and medical data were collected from WATCH pregnant women during their first study visit, as previously reported [43].

\subsection{Statistical Analysis}

Maternal and child characteristics were summarised using median and interquartile range (IQR) for continuous variables, and frequencies and percentages for categorical 
variables. The maternal characteristics of the WATCH women $(n=69)$ included in this study were compared to women that were excluded due to missing dietary and/or cognition and behaviour data $(n=113)$ using Fisher's exact tests. Further comparisons were made between the maternal age of both groups using a two-sample t-test. During early and late pregnancy, mean maternal intakes of energy, protein, total fat, saturated fatty acids (SFA), monounsaturated fatty acids, PUFA, omega- $3(n-3)$ fatty acids, omega- $6(n-6)$ fatty acids, total carbohydrate, total sugars (including fructose, glucose, sucrose, maltose, lactose and galactose), starch (polysaccharides including amylose, amylopectin, glycogen and dextrins) and fibre (souble and non-souble sources including non-starch polysaccharides and lignin) were expressed as kilojoules (KJ), total intakes (grams), percentage of total energy intake $(\% \mathrm{E})$, and the ratio of protein to carbohydrate (P:C) and ratio of fatty acids $n-6: n-3$. Nutrient intakes were adjusted for energy using the residual method [53]. Child body mass index (BMI) was converted to z-scores using the World Health Organization (WHO) Child Growth Standard references data [54]. To address potential misreporting of dietary intake, the pregnancy energy cut-off values recommended by Meltzer et al. [55] were applied which excluded women who reported daily energy intakes $<4.5$ or $>20.0 \mathrm{MJ} /$ day. Robust linear regression models were developed to determine the association of maternal macronutrient intake on child cognitive and behavioural outcomes. Maternal macronutrient intake data were transformed (natural logarithm) to achieve linearity. Analyses were adjusted for maternal age, education, pre-pregnancy BMI, birthweight and duration of breastfeeding (weeks) as they are significant predictors for child cognitive and behavioural outcomes. Sensitivity analyses were conducted using linear regression models that were not adjusted for total energy intake nor confounders to assess the impact on the study results. All tests assumed a 5\% significance level. All statistical analyses were performed using STATA 13 (Stata, College Station, TX, USA).

\section{Results}

Of the 182 women recruited, 69 women provided dietary data during early (6-24 weeks gestation) and late pregnancy (24-40 weeks gestation) (Figure 1). Five women reported implausible dietary intakes and were excluded from the analysis. Maternal dietary data and child cognition data were available from 58 mother-child dyads, while maternal dietary data and child behavioural data were available from 51 mother-child dyads. The characteristics of the WATCH mother-child dyads are summarised in Table 1. In summary, the characteristics of the women were median (IQR) 29 (7) years of age, married (63\%), with $36 \%$ having attained a university degree and $89 \%$ were non-smokers. Birthweights were median (IQR) 3590 (770) grams.

Sociodemographic, maternal, and medical data were self-reported by the participants in a questionnaire.

Cognition scores at age 4 years were: Full Scale IQ 108 (99-114), Verbal IQ 105 (98-111), Performance IQ 107 (100-118), PSQ 108 (101-114) and GLC 108 (97-117). For Full Scale IQ $66 \%$ of the WATCH children exceeded the mean \pm SD of Australian norms (100 \pm 15$)$ [51]. The median(IQR) behaviour scores at age 4 years were: emotionally reactive 54 (50-81), anxious/depressed 54 (50-73), somatic complaints 50 (50-62), withdrawn 73 (54-84), sleep problems 54 (50-73), attention problems 54 (50-76), aggressive behaviour 50 (50-73), and stress 62 (54-90), total problems 50 (17-69), internalizing 46 (24-79) and externalizing 38 (16-76). For total problems, internalizing and externalizing behaviour, 38\%, 39\% and 33\% of the WATCH children exceeded the American norms (50 \pm 10$)$, respectively [51].

The maternal macronutrient composition of the dietary intakes of the pregnant women are summarised in Table 2. Carbohydrate intake (median: $42 \%$ of total energy intake) of the WATCH cohort was within the acceptable macronutrient distribution range (AMDR) of $45-65 \%$ of total energy intake [56]. Median starch intake was $99.2 \mathrm{~g}$ per day. Currently, there is no nutrient reference value (NRV) set for starch intake and, therefore, low, medium and high consumers could not be determined. Protein intake (median: 19\% of total energy intake) was within the AMDR of 5-20\% of total energy intake [56]. Total fat intake (median: 
$37 \%$ of total energy intake) of the WATCH women was above the AMDR of $20-35 \%$ of total energy intake [56]. Maternal saturated fat intake (median: $16 \%$ of total energy intake) exceeded the AMDR of $\leq 10 \%$ of total energy intake, consistent with other studies [57-59].

Table 1. Characteristics of the WATCH mother-child dyads included in the analysis $(n=64)$.

\begin{tabular}{|c|c|c|}
\hline \multicolumn{3}{|c|}{ Characteristics } \\
\hline Pregnant Women & Median (IQR) $^{1}$ & Range Difference \\
\hline Maternal Age (y) & $29(7)$ & 22.4 \\
\hline Education & $n$ & $\%$ \\
\hline No formal qualification & 1 & 1.6 \\
\hline Year 10 or equivalent & 10 & 16 \\
\hline Year 12 or equivalent & 11 & 17 \\
\hline Trade/apprenticeship & 2 & 3.1 \\
\hline Certificate/diploma & 14 & 22 \\
\hline University degree & 23 & 36 \\
\hline Higher university degree & 3 & 4.7 \\
\hline Missing & 0 & 0 \\
\hline Household Weekly Income & $n$ & $\%$ \\
\hline No income & 0 & 0 \\
\hline \$AUD $^{1} 1-299$ & 4 & 6 \\
\hline \$AUD ${ }^{1} 300-699$ & 13 & 20 \\
\hline \$AUD ${ }^{1}$ 700-999 & 13 & 20 \\
\hline$\$$ AUD $^{1} 1000$ or more & 30 & 47 \\
\hline Unsure & 4 & 6 \\
\hline Missing & 0 & 0 \\
\hline Marital Status & $n$ & $\%$ \\
\hline Never married & 20 & 32 \\
\hline Married & 40 & 63 \\
\hline Separated/divorced & 3 & 4.8 \\
\hline Widowed & 0 & 0 \\
\hline Missing & 1 & 1.6 \\
\hline Maternal Smoking & $n$ & $\%$ \\
\hline Yes & 7 & 11 \\
\hline No & 57 & 89 \\
\hline Missing & 0 & 0 \\
\hline Maternal Depression & $n$ & $\%$ \\
\hline Yes & 17 & 27 \\
\hline No & 46 & 72 \\
\hline Missing & 1 & 1.6 \\
\hline Maternal Anxiety & $n$ & $\%$ \\
\hline Yes & 9 & 14 \\
\hline No & 54 & 84 \\
\hline Missing & 1 & 1.6 \\
\hline Previous Live Births(>37 Weeks Gestation) & $n$ & $\%$ \\
\hline None & 34 & 53 \\
\hline $1-2$ & 26 & 41 \\
\hline $3-4$ & 4 & 6.2 \\
\hline$>5$ & 0 & 0 \\
\hline Missing & 0 & 0 \\
\hline
\end{tabular}

${ }_{1}$ \$AUD, Australian dollars; IQR, interquartile range. 
Table 2. Maternal dietary composition * during pregnancy $(n=69)$.

\begin{tabular}{|c|c|c|c|}
\hline Nutrients & Daily NRVs & Daily Intake & $\%$ of Energy \\
\hline Energy (KJ) & & $\begin{array}{c}7095.7(5860.3 \\
8610.73)\end{array}$ & $n / a$ \\
\hline Protein $(\mathrm{g})$ & $5-20^{\dagger}$ & $78.5(66.0,101.7)$ & $19.4(17.8,21.1)$ \\
\hline Total fat (g) & $20-35^{\dagger}$ & $71.2(58.1,85.9)$ & $37.3(34.2,39.7)$ \\
\hline SFA $(g)$ & $\leq 10^{+}$ & $29.4(23.2,36.9)$ & $15.9(13.1,17.7)$ \\
\hline PUFA (g) & & $10.9(8.1,13.0)$ & $5.2(4.4,6.5)$ \\
\hline MUFA (g) & & $24.5(19.9,29.4)$ & $12.7(11.8,13.9)$ \\
\hline Total carb. (g) & $45-65^{\dagger}$ & $181.8(153.7,234.3)$ & $42.1(39.5,44.8)$ \\
\hline Sugars (g) & $\leq 25 \%{ }^{\dagger}$ & $89.9(72.3,110.6)$ & $19.9(17.3,22.0)$ \\
\hline Starch (g) & & $96.9(79.6,118.2)$ & $21.3(20.0,23.6)$ \\
\hline Fibre $(\mathrm{g})$ & $25(\mathrm{AI})^{\S}$ & $19.4(15.1,23.7)$ & $4.3(3.7,4.9)$ \\
\hline $\mathrm{P}: \mathrm{C}$ ratio $(\mathrm{g})$ & & $2.0(1.0,3.0)$ & $n / a$ \\
\hline \multicolumn{4}{|l|}{$\begin{array}{l}\text { Energy-adjusted } \\
\text { values }(n=64)\end{array}$} \\
\hline Energy (KJ) & & $7317.0(5984.2,8706.3)$ & $n / a$ \\
\hline Protein $(\mathrm{g})$ & $5-20^{+}$ & $81.1(69.2,103.6)$ & $19.2(17.7,21.0)$ \\
\hline Total fat (g) & $20-35^{\dagger}$ & $72.3(60.4,87.4)$ & $37.3(34.7,40.0)$ \\
\hline SFA $(g)$ & $\leq 10^{+}$ & $30.3(25.0,38.8)$ & $16.0(13.4,17.8)$ \\
\hline PUFA (g) & & $11.2(8.8,13.1)$ & $5.2(4.4,6.6)$ \\
\hline MUFA (g) & & $24.9(20.9,31.4)$ & $12.6(11.8,13.9)$ \\
\hline Total carb. (g) & $45-65^{+}$ & $186.1(156.8,237.6)$ & $42.0(39.5,44.7)$ \\
\hline Total Sugars (g) & $\leq 25 \%{ }^{\dagger}$ & $92.6(74.3,113.2)$ & $19.9(16.6,22.0)$ \\
\hline Starch (g) & & $99.2(80.4,120.9)$ & $21.3(19.8,23.7)$ \\
\hline Fibre $(\mathrm{g})$ & $25(\mathrm{AI}) \S$ & $20.9(15.7,24.3)$ & $4.2(3.6,4.9)$ \\
\hline $\mathrm{P}: \mathrm{C}$ ratio $(\mathrm{g})$ & & $2.0(1.0,3.0)$ & $n / \mathrm{a}$ \\
\hline
\end{tabular}

* All values are medians (25th and 75th percentiles). AI, adequate intake; carb., carbohydrate; P:C, protein-tocarbohydrate; SFA, saturated fatty acids; PUFA, polyunsaturated fatty acids; MUFA, monounsaturated fatty acids; NRVs, nutrient reference values. All values are medians (25th and 75 th percentiles). ${ }^{\dagger}$ Food and Nutrition Board: Institute of Medicine (FNB: IOM) reference values used for adults—carbohydrates: $45-65 \%$ energy intake, added sugar: $\leq 25 \%$ of total energy intake, protein: $5-20 \%$ energy intake, total fat: $20-35 \%$ energy intake, and saturated fatty acids: $\leq 10 \%$ energy intake. ${ }^{\S}$ National Health and Medical Research Council (NHMRC) Nutrient Reference Values for women aged 19-50 years.

Results of the mixed-models regression analyses examining the association between macronutrient composition during pregnancy and child cognitive and behavioural outcomes are provided in Tables 3 and 4. There was a non-significant trend indicated for each log-transformed additional gram of total carbohydrate intake consumed during pregnancy, child Performance IQ decreased (worsened) by approximately 15\% (25 points out of a maximum score of 160). The log-transformed maternal starch intake during pregnancy was negatively associated with performance IQ $(b=-11.02, p=0.03)$. For each log-transformed additional gram of starch consumed during pregnancy, child performance IQ was lower by approximately 11 points out of a maximum score of 160 . Based on the R-squared value, $26 \%$ of the variation in the outcome was accounted for in the linear regression model. Although this association was not statistically significant when maternal starch intake was not adjusted for energy intake $(b=-8.06, p=0.07$ (Table S1)). We have estimated that the Australian Guide to Healthy Eating (AGHE) [60] core food groups (i.e., bread and cereals, vegetables, fruit, dairy and alternatives, meat and alternatives) and the non-core foods (i.e., energy-dense nutrient poor foods that provide $600 \mathrm{KJ}$ per serve) contributed to $76 \%$ and $24 \%$ of maternal starch intake per day (data not shown). 
Table 3. Association of maternal dietary composition during pregnancy with child cognition outcomes up to age 4 years $(n=58)$.

\begin{tabular}{|c|c|c|c|c|}
\hline Variables $^{1}$ & Beta-Coefficient & 95\% Confidence Interval & $p$-Value ${ }^{2}$ & $R$-Value \\
\hline \multicolumn{5}{|c|}{ Full Scale IQ } \\
\hline Energy & -1.27 & -11.45 to 8.91 & 0.80 & 0.15 \\
\hline Protein $(\% \mathrm{E})$ & 5.29 & -19.53 to 30.10 & 0.68 & 0.16 \\
\hline Total fat (\% E) & 14.01 & -9.19 to 37.20 & 0.23 & 0.18 \\
\hline PUFA (\% E) & 1.70 & -6.96 to 10.37 & 0.70 & 0.15 \\
\hline $\mathrm{CHO}(\% \mathrm{E})$ & -20.55 & -46.12 to 5.01 & 0.11 & 0.19 \\
\hline $\mathrm{P}: \mathrm{C}$ ratio & -0.73 & -7.20 to 5.75 & 0.82 & 0.15 \\
\hline Protein $(\mathrm{g})$ & 0.33 & -9.79 to 9.13 & 0.94 & 0.15 \\
\hline PUFA (g) & 0.53 & -6.61 to 7.67 & 0.88 & 0.05 \\
\hline Total sugars $(\mathrm{g})$ & -0.51 & -8.50 to 7.49 & 0.90 & 0.15 \\
\hline Starch $(\mathrm{g})$ & -6.81 & -16.02 to 2.40 & 0.14 & 0.19 \\
\hline \multicolumn{5}{|c|}{ Verbal IQ } \\
\hline Energy & 3.79 & -9.73 to 17.31 & 0.58 & 0.06 \\
\hline Protein $(\% \mathrm{E})$ & -1.51 & -34.61 to 31.59 & 0.93 & 0.05 \\
\hline Total fat (\% E) & 19.83 & -10.80 to 50.45 & 0.20 & 0.08 \\
\hline PUFA (\% E) & 0.20 & -11.21 to 11.61 & 0.97 & 0.05 \\
\hline $\mathrm{CHO}(\% \mathrm{E})$ & -19.41 & -53.73 to 14.91 & 0.26 & 0.07 \\
\hline $\mathrm{P}: \mathrm{C}$ ratio & -3.56 & -12.12 to 5.00 & 0.41 & 0.06 \\
\hline Protein (g) & 3.05 & -9.51 to 15.62 & 0.63 & 0.05 \\
\hline PUFA (g) & 1.98 & -7.45 to 11.41 & 0.68 & 0.05 \\
\hline Total sugars $(\mathrm{g})$ & 2.46 & -8.16 to 13.09 & 0.64 & 0.05 \\
\hline Starch $(\mathrm{g})$ & -2.23 & -14.75 to 10.27 & 0.72 & 0.05 \\
\hline \multicolumn{5}{|c|}{ Performance IQ } \\
\hline Energy & -5.75 & -17.14 to 5.64 & 0.32 & 0.20 \\
\hline Protein (\% E) & 14.14 & -13.68 to 41.96 & 0.31 & 0.20 \\
\hline Total fat (\% E) & 11.70 & -14.69 to 38.11 & 0.38 & 0.20 \\
\hline PUFA (\% E) & -0.39 & -10.19 to 9.42 & 0.94 & 0.19 \\
\hline $\mathrm{CHO}(\% \mathrm{E})$ & -24.67 & -53.48 to 4.14 & 0.09 & 0.23 \\
\hline $\mathrm{P}: \mathrm{C}$ ratio & 1.85 & -5.46 to 9.15 & 0.61 & 0.19 \\
\hline Protein (g) & -2.91 & -13.56 to 7.74 & 0.59 & 0.19 \\
\hline PUFA (g) & -3.09 & -11.12 to 4.93 & 0.44 & 0.20 \\
\hline Total sugars $(\mathrm{g})$ & -3.78 & -12.71 to 5.16 & 0.40 & 0.20 \\
\hline Starch $(\mathrm{g})$ & -11.02 & -21.19 to -0.84 & 0.03 & 0.26 \\
\hline \multicolumn{5}{|c|}{ Processing Speed Composite } \\
\hline Energy & 0.92 & -9.83 to 11.67 & 0.86 & 0.18 \\
\hline Protein $(\% \mathrm{E})$ & 2.73 & -20.56 to 26.03 & 0.81 & 0.18 \\
\hline Total fat (\% E) & 6.14 & -16.24 to 28.52 & 0.58 & 0.19 \\
\hline PUFA (\% E) & -0.13 & -8.09 to 7.84 & 0.98 & 0.18 \\
\hline $\mathrm{CHO}(\% \mathrm{E})$ & -12.23 & -36.63 to 12.17 & 0.32 & 0.20 \\
\hline $\mathrm{P}: \mathrm{C}$ ratio & 3.17 & -2.72 to 9.05 & 0.28 & 0.20 \\
\hline PUFA (g) & 0.31 & -6.90 to 7.52 & 0.93 & 0.18 \\
\hline Protein $(\mathrm{g})$ & 1.14 & -8.22 to 10.49 & 0.81 & 0.18 \\
\hline Total sugars $(\mathrm{g})$ & 0.80 & -6.86 to 8.47 & 0.83 & 0.18 \\
\hline Starch $(\mathrm{g})$ & -4.69 & -15.57 to 6.19 & 0.39 & 0.20 \\
\hline
\end{tabular}


Table 3. Cont.

\begin{tabular}{ccccc}
\hline Variables $^{\mathbf{1}}$ & Beta-Coefficient & 95\% Confidence Interval & $p$-Value & $\boldsymbol{R}$-Value \\
\hline Energy & \multicolumn{2}{c}{ General Language Composite } & & \\
\hline Protein $(\% \mathrm{E})$ & 2.86 & -12.76 to 18.49 & 0.72 & 0.06 \\
\hline Total fat $(\% \mathrm{E})$ & 4.05 & -34.13 to 42.24 & 0.83 & 0.05 \\
\hline PUFA $(\% \mathrm{E})$ & 22.65 & -12.72 to 58.01 & 0.20 & 0.09 \\
\hline CHO $(\% \mathrm{E})$ & 4.01 & -9.11 to 17.14 & 0.54 & 0.06 \\
\hline P:C ratio & -24.03 & -63.56 to 15.51 & 0.23 & 0.08 \\
\hline Protein $(\mathrm{g})$ & -1.88 & -11.82 to 8.05 & 0.71 & 0.06 \\
\hline PUFA $(\mathrm{g})$ & 3.05 & -11.46 to 17.56 & 0.68 & 0.06 \\
\hline Total sugars $(\mathrm{g})$ & 4.14 & -6.71 to 14.98 & 0.45 & 0.07 \\
\hline Starch $(\mathrm{g})$ & 3.04 & -9.21 to 15.30 & 0.62 & 0.06 \\
\hline CHO & -6.11 & -20.47 to 8.24 & 0.40 & 0.07 \\
\hline
\end{tabular}

$\overline{\mathrm{CHO}}$, carbohydrates; $\mathrm{P}: \mathrm{C}$, protein to carbohydrate; PUFA, polyunsaturated fatty acids; \% E, percentage of energy. Analysis models were adjusted for energy intake, maternal age, education, pre-pregnancy BMI, breastfeeding duration (weeks) and birthweight. ${ }^{1}$ The natural logarithm transformation of the nutrient variable was used for the linear regression models to meet normality assumptions. ${ }^{2} p$-values were derived by linear regression models.

Table 4. Association of maternal dietary composition during pregnancy with child behaviour outcomes up to age 4 years $(n=51)$.

\begin{tabular}{|c|c|c|c|c|}
\hline Variables $^{1}$ & Beta-Coefficient & 95\% Confidence Interval & $p$-Value ${ }^{2}$ & $R$-Value \\
\hline \multicolumn{5}{|c|}{ Total Problems Score } \\
\hline Energy & 15.02 & -15.61 to 45.66 & 0.33 & 0.25 \\
\hline Protein (\% E) & 18.11 & -56.01 to 92.22 & 0.63 & 0.23 \\
\hline PUFA (\% E) & -19.98 & -47.31 to 7.34 & 0.15 & 0.27 \\
\hline Total fat (\% E) & -14.87 & -90.95 to 61.21 & 0.70 & 0.13 \\
\hline $\mathrm{CHO}(\% \mathrm{E})$ & 26.5887 & -57.25 to 110.42 & 0.53 & 0.24 \\
\hline $\mathrm{P}: \mathrm{C}$ ratio & 12.88 & -6.93 to 32.69 & 0.20 & 0.26 \\
\hline Protein $(g)$ & 15.55 & -12.71 to 43.81 & 0.27 & 0.25 \\
\hline PUFA (g) & -4.60 & -26.18 to 16.98 & 0.67 & 0.23 \\
\hline Total sugars $(\mathrm{g})$ & 17.51 & -6.50 to 41.51 & 0.15 & 0.27 \\
\hline Starch $(\mathrm{g})$ & 12.0573 & -18.14 to 42.2 & 0.43 & 0.24 \\
\hline \multicolumn{5}{|c|}{ Internalizing Broad Band Score } \\
\hline Energy & -1.47 & -32.06 to 29.13 & 0.92 & 0.27 \\
\hline Protein $(\%$ E) & 4.11 & -69.30 to 77.52 & 0.91 & 0.27 \\
\hline Total fat (\% E) & -10.67 & -85.89 to 64.54 & 0.78 & 0.27 \\
\hline PUFA (\% E) & -21.99 & -48.82 to 4.84 & 0.11 & 0.32 \\
\hline $\mathrm{CHO}(\% \mathrm{E})$ & 23.54 & -59.35 to 106.44 & 0.57 & 0.28 \\
\hline $\mathrm{P}: \mathrm{C}$ ratio & 11.54 & -8.10 to 31.18 & 0.24 & 0.30 \\
\hline Protein $(\mathrm{g})$ & -0.64 & -28.95 to 27.66 & 0.96 & 0.27 \\
\hline PUFA (g) & -13.84 & -34.79 to 7.11 & 0.19 & 0.30 \\
\hline Total sugars (g) & 4.56 & -19.69 to 28.81 & 0.71 & 0.27 \\
\hline Starch (g) & -0.26 & -30.30 to 29.79 & 0.99 & 0.27 \\
\hline
\end{tabular}


Table 4. Cont.

\begin{tabular}{|c|c|c|c|c|}
\hline Variables $^{1}$ & Beta-Coefficient & 95\% Confidence Interval & $p$-Value $^{2}$ & $R$-Value \\
\hline \multicolumn{5}{|c|}{ Externalizing Broad Band Score } \\
\hline Energy & 23.00 & -7.57 to 53.58 & 0.14 & 0.22 \\
\hline Protein $(\% \mathrm{E})$ & 18.93 & -56.11 to 93.97 & 0.61 & 0.19 \\
\hline Total fat (\% E) & 1.68 & -75.49 to 78.86 & 0.97 & 0.18 \\
\hline PUFA (\% E) & -17.55 & -45.39 to 10.29 & 0.21 & 0.21 \\
\hline $\mathrm{CHO}(\% \mathrm{E})$ & -0.52 & -88.14 to 87.11 & 0.99 & 0.11 \\
\hline $\mathrm{P}: \mathrm{C}$ ratio & 11.48 & -8.67 to 31.63 & 0.26 & 0.21 \\
\hline Protein $(\mathrm{g})$ & 22.50 & -5.70 to 50.70 & 0.12 & 0.23 \\
\hline
\end{tabular}

$\overline{\mathrm{CHO}}$, carbohydrates; P:C, protein to carbohydrate; PUFA, polyunsaturated fatty acids; \% E, percentage of energy. Analysis models were adjusted for energy intake, maternal age, education, pre-pregnancy BMI, birthweight and breastfeeding duration (weeks). ${ }^{1}$ The natural logarithm transformation of the nutrient variable was used for the linear regression models to meet normality assumptions. ${ }^{2} p$-values were derived by linear regression models.

Child externalizing behaviour did show a positive trend with log-transformed maternal protein $(b=27.71, p=0.05)$ and sugar intake $(b=24.19, p=0.05)$ but was not statistically significant. However, when the data were adjusted for breastfeeding duration (weeks), the strength of these associations was reduced $(p \geq 0.05)$. The associations between crude maternal nutrient intake and child behavioural outcomes are provided in Table S2. Analysis models without adjustments for confounding factors are provided in Tables S3 and S4. These sensitivity analyses did not detect any significant differences compared to the study findings presented. Maternal P:C ratio was not associated with child cognitive or behavioural outcomes, $p>0.05$. The R-squared values for the linear regression models indicated that each adjusted model accounted for between 5 to $32 \%$ of the total variance in the child cognitive or behavioural outcomes.

\section{Discussion}

To our knowledge, this is the first human study that has evaluated the association between macronutrient profiles during pregnancy on subsequent child cognitive and behavioural outcomes at age 4 years. This study identified increasing carbohydrate intake during pregnancy was negatively associated with child Performance IQ, a measure of non-verbal reasoning, attention and visuo-spatial processing. However, this relationship was not significant. Although there is evidence to support that an abnormal carbohydrate metabolism during pregnancy such as impaired glucose tolerance (IGT) and gestational diabetes mellitus (GDM) is adversely associated with child cognitive outcomes [61-63]. For example, $\mathrm{Xu}$ et al. [62] reported that children born to mothers with GDM ( $n=1421)$ had lower total wide-range assessment of visual motor abilities scores (WRAVMA), a measure of visual-spatial and fine motor ability, at 3 years of age compared with children born to mothers with normal glucose tolerance $(n=1187)$ ( -3.09 points; $95 \%$ confidence interval $(\mathrm{CI})-6.12,-0.05)$. Interestingly, child Performance IQ was negatively associated with maternal starch intake during pregnancy in which the relationship was statistically significant $(p=0.03)$. Starch is a complex carbohydrate that consists of polysaccharides, consumed from plant-based foods (e.g., oats, rice, potato) [64]. In the WATCH cohort, maternal starch intake (median: $99.2 \mathrm{~g}$ per day) only varied by $2 \%$ compared to the $2011-$ 2012 national averages reported in women 19-50 years [65]. The current study reported that non-core foods significantly contributed (24\%) to maternal starch intake [65]. These findings are supported by national data which indicated that processed cereal products and dishes (e.g., biscuits, pastries, pizza) are a major contributor (31\%) to daily starch intake in women aged 19-50 years [65]. This is concerning as these foods contain a higher proportion of rapidly digested starches and significantly less resistant starches which are lost during various food processing methods (e.g., milling, cooking, high-pressure processing) [66,67]. A higher consumption of rapidly digested starches contributes to increased de novo lipogenesis and attenuates the deposition of triglycerides into adipocytes throughout the 
body [68]. Triglycerides are chemically stable when stored in adipocytes [69-71]. However, once storage is at saturation, triglycerides may be deposited in non-adipose tissues such as the liver, heart and pancreas, which can lead to lipotoxicity and inflammation [69-71]. In the current study, it could be hypothesised that higher intakes of rapidly digested starches alters lipid metabolism and adversely impacts on cell, tissue and organ structure and function in the central nervous system, potentially contributing to a decline in child Performance IQ. This could not be evaluated in the current study, as specific types of starch could not be quantified using NUTTAB-95 data. Therefore, further investigation is warranted in future studies where detailed information on types of starch is available.

Resistant starch is the portion of starch that is resistant to degradation by the enzyme $\alpha$-amylase in the small intestine [72]. Instead, it is fermented in the colon by several bacteria groups (e.g., amylolytic gut bacteria) releasing fermentation products including short-chain fatty acids (acetate, propionate, butyrate, and valerate), branched-chain fatty acids (isovaleric and isobutyric acids), ammonia, amines, phenolic compounds and gases (methane, hydrogen, carbon dioxide) [72]. Colonic metabolites including short-chain fatty acids (acetate, propionate, butyrate, and valerate) are associated with a number of health benefits on gastrointestinal health, insulin sensitivity and weight management [72,73]. For example, short-chain fatty acids propionate stimulates the secretion of gut hormone peptides $Y Y$ (PYY) and glucagon-like peptide 1 (GLP-1) which are essential for appetite regulation and glucose homeostasis [74]. Butyrate is associated with being an anti-inflammatory agent by inhibiting the activation of transcription factors, NF- $\mathrm{kB}$ which regulates the expression of genes associated with inflammation (e.g., cytokines, adhesion molecules, acute-phase proteins) [75].

The impact of resistant starch on brain function and cognition has not been well explored [76-78]. However, emerging evidence suggests that resistant starch may impact on cognitive function by altering the serotonergic (5-HT) system that controls the activity of neurotransmitters $[79,80]$. Animal studies have shown that a high fat diet in rats during adulthood alters the density of serotonergic receptors in the brain $[81,82]$ and such adverse changes can be reversed by the intake of resistant starch and galacto-oligosaccharides [76]. Further research is greatly needed in this area, especially during pregnancy, to provide further insight in relation to these findings. This evidence will be important as modifying resistant starch intake could potentially be used as a therapeutic intervention for improving brain function and cognition.

Limitations in the current study need to be acknowledged and include the use selfreported dietary data. Therefore, the possibility of mis-reporting cannot be excluded. To improve the validity of reported total energy intakes, the pregnancy energy cut-off values recommended by Meltzer et al. [55] were applied ( $<4.5$ or $>20.0 \mathrm{MJ} /$ day). Dietary data are further strengthened by similarities between the WATCH median energy-adjusted intake (7317 KJ) and the Australian Longitudinal Study on Women's Health (ALSWH) mean energy intake (7795 KJ) [83]. Maternal macronutrient profile was similar to the 2011-2012 national averages reported in women aged $19-50$ years [65]. The most variation can be seen in the median maternal fat intake, which was $5 \%$ higher compared to the national average [65]. While median protein and carbohydrate intake only varied by $1 \%$ compared to the national average [65]. These findings indicate that the dietary intake of this cohort is generalizable to women in the Australian population. The WATCH study has previously demonstrated a positive correlation between all dietary variables during early and late pregnancy [24]. Maternal nutrient intake was quantified using NUTTAB-1995 which was the most comprehensive database at the time of the study. However, specific data were not available for new food products produced after 1995. While study findings may be confounded by postnatal diet which was not explored in the current analyses. Although the regression models were adjusted for breastfeeding duration. Previously analyses from the WATCH cohort demonstrated that maternal diet during 2-3 years of the postnatal period was correlated with the overall dietary quality in the offspring $(p<0.001)$ [84]. 
The measurement of cognition and behaviour are known to be affected by a child's mood, motivation, anxiety, energy levels, and personal effort [85]. To address this, the WATCH study monitored the children's energy levels and mental concentration and prioritized the cognition subsets that were necessary to produce IQ scores. Furthermore, child cognitive function is also influenced by genetics, biomedical, social and environmental factors that have not been explored in the current analyses [86,87]. Child cognitive and behavioural outcomes were not deemed the primary outcomes when the WATCH study was established. Due to the extended length of follow up, attrition was high and the sample size was small $(n=64)$. This study is likely to be underpowered to detect the associations between maternal macronutrient intake and child cognition and behavioural outcomes. The analysis of this study was exploratory and therefore multiple variables were used to provide a wide scope of data and inform future research in this area. However, the use of multiple predictors within a small sample size may have increased the risk of type I error within the dataset. Lastly, causality cannot be inferred as this is a prospective cohort study. Therefore, the observed relationships require further investigation in experimental studies.

\section{Conclusions}

This prospective cohort study found that child Performance IQ at 4 years was inversely associated with maternal starch intake. There is an opportunity for future cohort studies to investigate the relationship between intake of different types of starch consumed during pregnancy with lipid metabolism and child cognitive development.

Supplementary Materials: The following are available online at https:/ / www.mdpi.com/article/10 .3390 / children8050425/s1, Table S1: Association of maternal dietary composition during pregnancy with child cognition outcomes up to age 4 years $(n=58)$; Table S2. Association of maternal dietary composition during pregnancy with child behaviour outcomes up to age 4-years $(n=51)$; Association of maternal dietary composition during pregnancy with child cognition outcomes up to age 4years $(n=58)$ without adjustment for covariates; Association of maternal dietary composition during pregnancy with child behaviour outcomes up to age 4-years $(n=51)$ without adjustment for covariates

Author Contributions: Conceptualization, M.L.B., A.J.H., R.S. and C.E.C.; methodology, R.M.T., M.L.B., L.M.A., N.B., K.D. and C.E.C.; formal analysis, R.M.T., M.L.B. and L.M.A.; investigation, R.M.T., M.L.B., A.J.H., L.M.A., N.B. and K.D.; data curation, R.M.T., M.L.B. and L.M.A.; writingoriginal draft preparation, R.M.T.; writing-review and editing, All authors; supervision, R.S. and C.E.C.; project administration, M.L.B., A.J.H., R.S. and C.E.C. All authors have read and agreed to the published version of the manuscript.

Funding: This research did not receive any specific grant from funding agencies in the public, commercial, or not-for-profit sectors. Professor Clare E Collins is supported by a National Health and Medical Research Council of Australia Senior Research Fellowship, and a Gladys M Brawn Senior Research Fellowship from the Faculty of Health and Medicine, the University of Newcastle, Australia.

Institutional Review Board Statement: This study was conducted according to the guidelines of the Declaration of Helsinki, and approved by the Hunter New England Research Ethics Committee (06/05/24/5.06).

Informed Consent Statement: Informed consent was obtained from all subjects involved in this study.

Data Availability Statement: Data are contained within the article or supplementary material.

Acknowledgments: We thank the women and their children that participated in the Women and Their Children's Health study.

Conflicts of Interest: The authors declare no conflict of interest. 


\section{References}

1. Gluckman, P.D.; Hanson, M.; Pinal, C. The developmental origins of adult disease. Matern. Child Nutr. 2005, 1, 130-141. [CrossRef] [PubMed]

2. Susser, E.; Neugebauer, R.; Hoek, H.W.; Brown, A.S.; Lin, S.; Labovitz, D.; Gorman, J.M. Schizophrenia After Prenatal Famine. Arch. Gen. Psychiatry 1996, 53, 25-31. [CrossRef] [PubMed]

3. Fox, S.E.; Levitt, P.; Nelson, C.A., III. How the Timing and Quality of Early Experiences Influence the Development of Brain Architecture. Child Dev. 2010, 81, 28-40. [CrossRef] [PubMed]

4. Dekaban, A.S.; Sadowsky, D. Changes in brain weights during the span of human life: Relation of brain weights to body heights and body weights. Ann. Neurol. 1978, 4, 345-356. [CrossRef] [PubMed]

5. Linderkamp, O.; Janus, L.; Linder, R.; Skoruppa, D.B. Time table of normal foetal brain development. Int. J. Prenat. Perinat. Psychol. Med. 2009, 21, 4-16.

6. Prado, E.L.; Dewey, K.G. Nutrition and brain development in early life. Nutr. Rev. 2014, 72, 267-284. [CrossRef]

7. Brown, A.S.; Susser, E.S.; Lin, S.P.; Neugebauer, R.; Gorman, J.M. Increased Risk of Affective Disorders in Males after Second Trimester Prenatal Exposure to the Dutch Hunger Winter of 1944-45. Br. J. Psychiatry 1995, 166, 601-606. [CrossRef]

8. Brown, A.S.; van Os, J.; Driessens, C.; Hoek, H.W.; Susser, E.S. Further evidence of relation between prenatal famine and major affective disorder. Am. J. Psychiatry 2000, 157, 190-195. [CrossRef]

9. Rodriguez, A. Maternal pre-pregnancy obesity and risk for inattention and negative emotionality in children. J. Child Psychol. Psychiatry 2010, 51, 134-143. [CrossRef]

10. Chen, Q.; Sjölander, A.; Långström, N.; Rodriguez, A.; Serlachius, E.; D’Onofrio, B.M.; Lichtenstein, P.; Larsson, H. Maternal pre-pregnancy body mass index and offspring attention deficit hyperactivity disorder: A population-based cohort study using a sibling-comparison design. Int. J. Epidemiol. 2014, 43, 83-90. [CrossRef]

11. Li, Y.M.; Ou, J.-J.; Liu, L.; Zhang, D.; Zhao, J.-P.; Tang, S.Y. Association Between Maternal Obesity and Autism Spectrum Disorder in Offspring: A Meta-analysis. J. Autism Dev. Disord. 2016, 46, 95-102. [CrossRef] [PubMed]

12. Moody, L.; Chen, H.; Pan, Y.-X. Early-Life Nutritional Programming of Cognition-The Fundamental Role of Epigenetic Mechanisms in Mediating the Relation between Early-Life Environment and Learning and Memory Process. Adv. Nutr. 2017, 8, 337-350. [CrossRef]

13. Xu, J.; He, G.; Zhu, J.; Zhou, X.; Clair, D.S.; Wang, T.; Xiang, Y.; Zhao, Q.; Xing, Q.; Liu, Y.; et al. Prenatal Nutritional Deficiency Reprogrammed Postnatal Gene Expression in Mammal Brains: Implications for Schizophrenia. Int. J. Neuropsychopharmacol. 2014, 18. [CrossRef]

14. He, F.; Lupu, D.S.; Niculescu, M.D. Perinatal $\alpha$-linolenic acid availability alters the expression of genes related to memory and to epigenetic machinery, and the Mecp2 DNA methylation in the whole brain of mouse offspring. Int. J. Dev. Neurosci. 2014, 36, 38-44. [CrossRef]

15. Dominguez-Salas, P.; Moore, S.E.; Baker, M.S.; Bergen, A.W.; Cox, S.E.; Dyer, R.A.; Fulford, A.J.; Guan, Y.; Laritsky, E.; Silver, M.J.; et al. Maternal nutrition at conception modulates DNA methylation of human metastable epialleles. Nat. Commun. 2014, 5, 3746. [CrossRef]

16. Dominguez-Salas, P.; E Moore, S.; Cole, D.; Da Costa, K.-A.; E Cox, S.; A Dyer, R.; Fulford, A.J.C.; Innis, S.M.; A Waterland, R.; Zeisel, S.H.; et al. DNA methylation potential: Dietary intake and blood concentrations of one-carbon metabolites and cofactors in rural African women. Am. J. Clin. Nutr. 2013, 97, 1217-1227. [CrossRef]

17. Switkowski, K.M.; Jacques, P.F.; Must, A.; Kleinman, K.P.; Gillman, M.W.; Oken, E. Maternal protein intake during pregnancy and linear growth in the offspring. Am. J. Clin. Nutr. 2016, 104, 1128-1136. [CrossRef]

18. Sloan, N.L.; Lederman, S.A.; Leighton, J.; Himes, J.H.; Rush, D. The effect of prenatal dietary protein intake on birth weight. Nutr. Res. 2001, 21, 129-139. [CrossRef]

19. Moore, V.M.; Davies, M.J.; Willson, K.J.; Worsley, A.; Robinson, J.S. Dietary Composition of Pregnant Women Is Related to Size of the Baby at Birth. J. Nutr. 2004, 134, 1820-1826. [CrossRef]

20. E Watson, P.; McDonald, B.W. The association of maternal diet and dietary supplement intake in pregnant New Zealand women with infant birthweight. Eur. J. Clin. Nutr. 2010, 64, 184-193. [CrossRef]

21. Hayward, C.E.; Greenwood, S.L.; Sibley, C.P.; Baker, P.N.; Challis, J.R.G.; Jones, R.L. Effect of maternal age and growth on placental nutrient transport: Potential mechanisms for teenagers' predisposition to small-for-gestational-age birth? Am. J. Physiol. Metab. 2012, 302, E233-E242. [CrossRef] [PubMed]

22. Iruloh, C.G.; D'Souza, S.W.; Fergusson, W.D.; Baker, P.N.; Sibley, C.P.; Glazier, J.D. Amino Acid Transport Systems $\beta$ and A in Fetal T Lymphocytes in Intrauterine Growth Restriction and With Tumor Necrosis Factor- $\alpha$ Treatment. Pediatr. Res. 2008, 65, 51-56. [CrossRef] [PubMed]

23. Battaglia, F.C.; Regnault, T.R.H. Placental Transport and Metabolism of Amino Acids. Placenta 2001, 22, 145-161. [CrossRef] [PubMed]

24. Blumfield, M.L.; Hure, A.J.; MacDonald-Wicks, L.K.; Smith, R.; Simpson, S.J.; Giles, W.B.; Raubenheimer, D.; Collins, C.E. Dietary balance during pregnancy is associated with fetal adiposity and fat distribution. Am. J. Clin. Nutr. 2012, 96, 1032-1041. [CrossRef]

25. Burdge, G.C.; Dunn, R.L.; Wootton, S.A.; Jackson, A.A. Effect of reduced dietary protein intake on hepatic and plasma essential fatty acid concentrations in the adult female rat: Effect of pregnancy and consequences for accumulation of arachidonic and docosahexaenoic acids in fetal liver and brain. Br. J. Nutr. 2002, 88, 379-387. [CrossRef] 
26. Resnick, O.; Miller, M.; Forbes, W.; Hall, R.; Kemper, T.; Bronzino, J.; Morgane, P.J. Developmental protein malnutrition: Influences on the central nervous system of the rat. Neurosci. Biobehav. Rev. 1979, 3, 233-246. [CrossRef]

27. Diáz-Cintra, S.; Cintra, L.; Galván, A.; Aguilar, A.; Kemper, T.; Morgane, P.J. Effects of prenatal protein deprivation on postnatal development of granule cells in the fascia dentata. J. Comp. Neurol. 1991, 310, 356-364. [CrossRef]

28. Granados-Rojas, L.; Larriva-Sahd, J.; Cintra, L.; Gutiérrez-Ospina, G.; Rondán, A.; Díaz-Cintra, S. Prenatal protein malnutrition decreases mossy fibers-CA3 thorny excrescences asymmetrical synapses in adult rats. Brain Res. 2002, 933, 164-171. [CrossRef]

29. Andrade, J.; Cadete-Leite, A.; Madeira, M.; Paula-Barbosa, M.M. Long-term low-protein diet reduces the number of hippocampal mossy fiber synapses. Exp. Neurol. 1991, 112, 119-124. [CrossRef]

30. Reyes-Castro, L.A.; Padilla-Gómez, E.; Parga-Martínez, N.J.; Castro-Rodríguez, D.C.; Quirarte, G.L.; Díaz-Cintra, S.; Nathanielsz, P.W.; Zambrano, E. Hippocampal mechanisms in impaired spatial learning and memory in male offspring of rats fed a low-protein isocaloric diet in pregnancy and/or lactation. Hippocampus 2018, 28, 18-30. [CrossRef]

31. Torres, N.; Bautista, C.J.; Tovar, A.R.; Ordáz, G.; Rodríguez-Cruz, M.; Ortiz, V.; Granados, O.; Nathanielsz, P.W.; Larrea, F.; Zambrano, E. Protein restriction during pregnancy affects maternal liver lipid metabolism and fetal brain lipid composition in the rat. Am. J. Physiol. Endocrinol. Metab. 2010, 298, E270-E277. [CrossRef]

32. Burdge, G.C.; Delange, E.; Dubois, L.; Dunn, R.L.; Hanson, M.A.; Jackson, A.A.; Calder, P.C. Effect of reduced maternal protein intake in pregnancy in the rat on the fatty acid composition of brain, liver, plasma, heart and lung phospholipids of the offspring after weaning. Br. J. Nutr. 2003, 90, 345-352. [CrossRef]

33. Reyes-Castro, L.; Rodriguez, J.; Rodríguez-González, G.; Wimmer, R.; McDonald, T.; Larrea, F.; Nathanielsz, P.; Zambrano, E. Preand/or postnatal protein restriction in rats impairs learning and motivation in male offspring. Int. J. Dev. Neurosci. 2011, 29, 177-182. [CrossRef]

34. Furuse, T.; Miyake, K.; Kohda, T.; Kaneda, H.; Hirasawa, T.; Yamada, I.; Kushida, T.; Kashimura, M.; Kobayashi, K.; Ishino, F.; et al. Protein-restricted diet during pregnancy after insemination alters behavioral phenotypes of the progeny. Genes Nutr. 2017, 12, 1. [CrossRef]

35. Reyes-Castro, L.; Rodriguez, J.; Charco, R.; Bautista, C.; Larrea, F.; Nathanielsz, P.; Zambrano, E. Maternal protein restriction in the rat during pregnancy and/or lactation alters cognitive and anxiety behaviors of female offspring. Int. J. Dev. Neurosci. 2012, 30, 39-45. [CrossRef] [PubMed]

36. Jacka, F.N.; Ystrom, E.; Brantsaeter, A.L.; Karevold, E.; Roth, C.; Haugen, M.; Meltzer, H.M.; Schjolberg, S.; Berk, M. Maternal and Early Postnatal Nutrition and Mental Health of Offspring by Age 5 Years: A Prospective Cohort Study. J. Am. Acad. Child Adolesc. Psychiatry 2013, 52, 1038-1047. [CrossRef]

37. Taylor, R.M.; Fealy, S.M.; Bisquera, A.; Smith, R.; Collins, C.E.; Evans, T.-J.; Hure, A.J. Effects of Nutritional Interventions during Pregnancy on Infant and Child Cognitive Outcomes: A Systematic Review and Meta-Analysis. Nutrients 2017, 9, 1265. [CrossRef]

38. Larson, L.M.; Yousafzai, A.K. A meta-analysis of nutrition interventions on mental development of children under-two in lowand middle-income countries. Matern. Child Nutr. 2017, 13, e12229. [CrossRef]

39. Bourre, J.-M. Effects of nutrients (in food) on the structure and function of the nervous system: Update on dietary requirements for brain. Part 1: Micronutrients. J. Nutr. Health Aging 2006, 10, 377-385.

40. Paulson, O.B. Blood-brain barrier, brain metabolism and cerebral blood flow. Eur. Neuropsychopharmacol. 2002, 12, 495-501. [CrossRef]

41. Hure, A.J.; Collins, C.E.; Giles, W.B.; Wright, I.; Smith, R. Protocol for the Women and Their Children's Health (WATCH) Study: A Cohort of Pregnancy and Beyond. J. Epidemiology 2012, 22, 267-275. [CrossRef] [PubMed]

42. Hure, A.J.; Smith, R.; Collins, C.E. A recruiting failure turned success. BMC Health Serv. Res. 2008, 8, 64. [CrossRef] [PubMed]

43. Hure, A.J.; Collins, C.E.; Giles, W.B.; Paul, J.W.; Smith, R. Greater Maternal Weight Gain During Pregnancy Predicts a Large but Lean Fetal Phenotype: A Prospective Cohort Study. Matern. Child Health J. 2012, 16, 1374-1384. [CrossRef] [PubMed]

44. von Elm, E.; Altman, D.G.; Egger, M.; Pocock, S.J.; Gøtzsche, P.C.; Vandenbroucke, J.P. The Strengthening the Reporting of Observational Studies in Epidemiology (STROBE) statement: Guidelines for reporting observational studies. Ann. Intern. Med. 2007, 147, 573-577. [CrossRef]

45. Blumfield, M.L.; Nowson, C.; Hure, A.J.; Smith, R.; Simpson, S.J.; Raubenheimer, D.; MacDonald-Wicks, L.; Collins, C.E. Lower Protein-to-Carbohydrate Ratio in Maternal Diet is Associated with Higher Childhood Systolic Blood Pressure up to Age Four Years. Nutrients 2015, 7, 3078-3093. [CrossRef]

46. Cancer Council Victoria. Dietary Questionnaire for Epidemiological Studies Version 2 (DQESv2); Australia Cancer Council: Melbourne, VIC, Australia, 2014.

47. Hodge, A.; Patterson, A.J.; Brown, W.J.; Ireland, P.; Giles, G. The Anti Cancer Council of Victoria FFQ: Relative validity of nutrient intakes compared with weighed food records in young to middle-aged women in a study of iron supplementation. Aust. N. Z. J. Public Health 2000, 24, 576-583. [CrossRef]

48. Wechsler, D. Wechsler Preschool and Primary Scale of Intelligence, 3rd ed.; Harvcourt Assessment Inc.: San Antonio, TX, USA, 2002.

49. Wechsler, D. WPPSI-III: Technical and Interpretative Manual; The Psychological Corporation: New York, NY, USA, 2002.

50. Wechsler, D. WPPSI-III Australian: Administration and Scoring Manual; Harcourt Assessment: Sydney, NSW, Australia, 2004.

51. Achenbach, T.; Rescorla, L. Manual for ASEBA School-age Forms and Profiles. In Research Center for Children, Youth, and Families; University of Vermont: Burlington, UK, 2001. 
52. Rescorla, L.A.; Achenbach, T.M.; Ivanova, M.Y.; Harder, V.S.; Otten, L.; Bilenberg, N.; Bjarnadottir, G.; Capron, C.; De Pauw, S.S.W.; Dias, P.; et al. International Comparisons of Behavioral and Emotional Problems in Preschool Children: Parents' Reports From 24 Societies. J. Clin. Child Adolesc. Psychol. 2011, 40, 456-467. [CrossRef]

53. Willett, W.C.; Howe, G.R.; Kushi, L.H. Adjustment for total energy intake in epidemiologic studies. Am. J. Clin. Nutr. 1997, 65, 1220S-1228S. [CrossRef]

54. Van den Broeck, J.; Willie, D.; Younger, N. The World Health Organization child growth standards: Expected implications for clinical and epidemiological research. Eur. J. Pediatr. 2009, 168, 247-251. [CrossRef]

55. Meltzer, H.M.; Brantsaeter, A.L.; Ydersbond, T.A.; Alexander, J.; Haugen, M.; The MoBa Dietary Support Group. Methodological challenges when monitoring the diet of pregnant women in a large study: Experiences from the Norwegian Mother and Child Cohort Study (MoBa). Matern. Child Nutr. 2008, 4, 14-27. [CrossRef]

56. Trumbo, P.; Schlicker, S.; Yates, A.A.; Poos, M. Dietary Reference Intakes for Energy, Carbohydrate, Fiber, Fat, Fatty Acids, Cholesterol, Protein and Amino Acids. J. Am. Diet. Assoc. 2002, 102, 1621-1630. [CrossRef]

57. Sharma, S.S.; Greenwood, D.C.; Simpson, N.A.B.; Cade, J. Is dietary macronutrient composition during pregnancy associated with offspring birth weight? An observational study. Br. J. Nutr. 2018, 119, 330-339. [CrossRef]

58. Hrolfsdottir, L.; Schalkwijk, C.G.; Birgisdottir, B.E.; Gunnarsdottir, I.; Maslova, E.; Granström, C.; Strøm, M.; Olsen, S.; Halldorsson, T.I. Maternal diet, gestational weight gain, and inflammatory markers during pregnancy. Obesity 2016, 24, 2133-2139. [CrossRef]

59. Savard, C.; Lemieux, S.; Weisnagel, S.J.; Fontaine-Bisson, B.; Gagnon, C.; Robitaille, J.; Morisset, A.-S. Trimester-Specific Dietary Intakes in a Sample of French-Canadian Pregnant Women in Comparison with National Nutritional Guidelines. Nutrients 2018, 10, 768. [CrossRef]

60. National Health and Medical Research Council (NHMRC). Eat for Health: Australian Dietary Guidelines. 2013. Available online: https:/ / www.eatforhealth.gov.au/sites/default/files/content/n55_australian_dietary_guidelines.pdf (accessed on 19 May 2021).

61. Rizzo, T.; Metzger, B.E.; Burns, W.J.; Burns, K. Correlations between Antepartum Maternal Metabolism and Intelligence of Offspring. N. Engl. J. Med. 1991, 325, 911-916. [CrossRef]

62. Xu, T.; Faleschini, S.; Rifas-Shiman, S.L.; Monthé-Drèze, C.; Oken, E.; Hivert, M.; Tiemeier, H. Maternal glucose tolerance in pregnancy and child cognitive and behavioural problems in early and mid-childhood. Paediatr. Périnat. Epidemiol. 2021, 35, 109-119. [CrossRef]

63. Fraser, A.; Nelson, S.; Macdonald-Wallis, C.; Lawlor, D.A. Associations of Existing Diabetes, Gestational Diabetes, and Glycosuria with Offspring IQ and Educational Attainment: The Avon Longitudinal Study of Parents and Children. Exp. Diabetes Res. 2012, 2012, 963735. [CrossRef]

64. Lovegrove, A.; Edwards, C.H.; De Noni, I.; Patel, H.; El, S.N.; Grassby, T.; Zielke, C.; Ulmius, M.; Nilsson, L.; Butterworth, P.J.; et al. Role of polysaccharides in food, digestion, and health. Crit. Rev. Food Sci. Nutr. 2017, 57, 237-253. [CrossRef]

65. Australian Bureau of Statistics (ABS). Australian Health Survey: Nutrition First Results-Foods and Nutrients, 2011-2012; ABS: Canberra, Australia, 2014.

66. Dundar, A.N.; Gocmen, D. Effects of autoclaving temperature and storing time on resistant starch formation and its functional and physicochemical properties. Carbohydr. Polym. 2013, 97, 764-771. [CrossRef]

67. Muir, J.G.; O'Dea, K. Measurement of resistant starch: Factors affecting the amount of starch escaping digestion in vitro. Am. J. Clin. Nutr. 1992, 56, 123-127. [CrossRef]

68. Higgins, J.A.; Brown, M.A.; Storlien, L.H. Consumption of resistant starch decreases postprandial lipogenesis in white adipose tissue of the rat. Nutr. J. 2006, 5, 25. [CrossRef] [PubMed]

69. Solinas, G.; Borén, J.; Dulloo, A.G. De novo lipogenesis in metabolic homeostasis: More friend than foe? Mol. Metab. 2015, 4, 367-377. [CrossRef] [PubMed]

70. Unger, R.H.; Clark, G.O.; Scherer, P.E.; Orci, L. Lipid homeostasis, lipotoxicity and the metabolic syndrome. Biochim. Biophys. Acta (BBA) Mol. Cell Biol. Lipids 2010, 1801, 209-214. [CrossRef] [PubMed]

71. Opazo-Ríos, L.; Mas, S.; Marín-Royo, G.; Mezzano, S.; Gómez-Guerrero, C.; Moreno, J.A.; Egido, J. Lipotoxicity and Diabetic Nephropathy: Novel Mechanistic Insights and Therapeutic Opportunities. Int. J. Mol. Sci. 2020, 21, 2632. [CrossRef]

72. Birt, D.F.; Boylston, T.; Hendrich, S.; Jane, J.-L.; Hollis, J.; Li, L.; McClelland, J.; Moore, S.; Phillips, G.J.; Rowling, M.; et al. Resistant Starch: Promise for Improving Human Health. Adv. Nutr. 2013, 4, 587-601. [CrossRef]

73. Ashwar, B.A.; Gani, A.; Shah, A.; Wani, I.A.; Masoodi, F.A. Preparation, health benefits and applications of resistant starch-a review. Starch Stärke 2016, 68, 287-301. [CrossRef]

74. Psichas, A.; Sleeth, M.L.; Murphy, K.G.; Brooks, L.; A Bewick, G.; Hanyaloglu, A.C.; A Ghatei, M.; Bloom, S.R.; Frost, G. The short chain fatty acid propionate stimulates GLP-1 and PYY secretion via free fatty acid receptor 2 in rodents. Int. J. Obes. 2015, 39, 424-429. [CrossRef]

75. Aguilar, E.; Leonel, A.; Teixeira, L.; Silva, A.; Silva, J.; Pelaez, J.; Capettini, L.; Lemos, V.; Santos, R.; Alvarez-Leite, J. Butyrate impairs atherogenesis by reducing plaque inflammation and vulnerability and decreasing NFkB activation. Nutr. Metab. Cardiovasc. Dis. 2014, 24, 606-613. [CrossRef]

76. Yu, Y.; Patch, C.; Weston-Green, K.; Zhou, Y.; Zheng, K.; Huang, X.-F. Dietary Galacto-Oligosaccharides and Resistant Starch Protect Against Altered CB1 and 5-HT1A and 2A Receptor Densities in Rat Brain: Implications for Preventing Cognitive and Appetite Dysfunction During a High-Fat Diet. Mol. Nutr. Food Res. 2018, 62, e1800422. [CrossRef] 
77. Zhou, J.; Keenan, M.J.; Fernandez-Kim, S.O.; Pistell, P.J.; Ingram, D.K.; Li, B.; Raggio, A.M.; Shen, L.; Zhang, H.; McCutcheon, K.L.; et al. Dietary resistant starch improves selected brain and behavioral functions in adult and aged rodents. Mol. Nutr. Food Res. 2013, 57, 2071-2074. [CrossRef]

78. Shen, L.; Keenan, M.J.; Martin, R.J.; Tulley, R.T.; Raggio, A.M.; McCutcheon, K.L.; Zhou, J. Dietary Resistant Starch Increases Hypothalamic POMC Expression in Rats. Obesity 2009, 17, 40-45. [CrossRef]

79. Gong, P.; Li, J.; Wang, J.; Lei, X.; Chen, D.; Zhang, K.; Zhang, W.; Zhen, A.; Gao, X.; Zhang, F. Variations in 5-HT2A influence spatial cognitive abilities and working memory. Can. J. Neurol. Sci. 2011, 38, 303-308. [CrossRef]

80. Wingen, M.; Kuypers, K.; Ramaekers, J.G. Selective verbal and spatial memory impairment after 5-HT1A and 5-HT2A receptor blockade in healthy volunteers pre-treated with an SSRI. J. Psychopharmacol. 2007, 21, 477-485. [CrossRef]

81. Yu, Y.; Wu, Y.; Patch, C.; Wu, Z.; Szabo, A.; Li, D.; Huang, X.-F. DHA prevents altered 5-HT1A, 5-HT2A, CB1 and GABAA receptor binding densities in the brain of male rats fed a high-saturated-fat diet. J. Nutr. Biochem. 2013, 24, 1349-1358. [CrossRef]

82. Wu, Z.; Yu, Y.; Wu, Y.; Patch, C.; Szabo, A.; Huang, X.-F. Reduction of histamine H1 receptor binding induced by high-fat diet can be prevented by DHA and dietary fiber in specific brain areas of male rats. Brain Res. Bull. 2013, 97, 119-125. [CrossRef]

83. Hure, A.; Young, A.; Smith, R.; Collins, C. Diet and pregnancy status in Australian women. Public Health Nutr. 2009, 12, 853-861. [CrossRef]

84. Ashman, A.M.; Collins, C.E.; Hure, A.J.; Jensen, M.; Oldmeadow, C. Maternal diet during early childhood, but not pregnancy, predicts diet quality and fruit and vegetable acceptance in offspring. Matern. Child Nutr. 2016, 12, 579-590. [CrossRef]

85. Isaacs, E.; Oates, J.; ILSI Europe, a.i.s.b.l. Nutrition and cognition: Assessing cognitive abilities in children and young people. Eur. J. Nutr. 2008, 47, 4-24. [CrossRef]

86. Deary, I.J.; Johnson, W.; Houlihan, L.M. Genetic foundations of human intelligence. Human Genet. 2009, 126, 215-232. [CrossRef]

87. Ford, N.D.; Stein, A.D. Risk factors affecting child cognitive development: A summary of nutrition, environment, and maternalchild interaction indicators for sub-Saharan Africa. J. Dev. Orig. Health Dis. 2016, 7, 197-217. [CrossRef] 